\title{
Experimental Transmission of Trypanosoma cruzi Through the Genitalia of Albino Mice
}

\author{
Leidi Herrera, Servio Urdaneta-Morales ${ }^{+}$
}

Laboratorio de Biología de Trypanosoma de Mamíferos, Instituto de Zoología Tropical, Facultad de Ciencias, Universidad Central de Venezuela, Apartado 47462, Los Chaguaramos, Caracas 1041-A, Venezuela

Trypanosoma cruzi is usually transmitted by contact with the excreta of infected Triatominae; among non-vectorial infections, direct transmission through coitus has been proposed. We investigated this possibility by instilling, through the external meatus of the vagina and the penis of previously anesthetized NMRI albino mice, blood of mice infected with strains isolated from Didelphis marsupialis (opossum, strain CO57), Rattus rattus (rat, strain CO22) and human (strain EP). Some animals were allowed to copulate the same day of the instillation. In other experiments, the strains were inoculated in the scrotum. To determine the effect of immunosuppression, some mice were treated with cyclophosphamide 30 days post-instillation. Controls were instilled orally and ocularly. Vaginal instillation with strain CO22 produced systemic infection with tropism to the heart, skeletal muscle, skin, duodenum, pancreas, ovary and sternum. Scrotal inoculation with strain EP likewise invaded liver, spleen, lung, lymph nodes and urogenital organs; while strain CO57 invaded skeletal and cardiac muscle, pancreas, testis, and vas deferens. Penile infection with strain CO22 was detected by xenodiagnosis. Immunosuppression did not increase parasitemia of vaginally infected mice or controls. Mating did not produce infection. Our results show that contact of blood trypomastigotes of $\mathrm{T}$. cruzi with genital mucosa can produce blood and tissue infections. These results are discussed in relation to reports of frequent experimental tropism of $\mathrm{T}$. cruzi toward urogenital organs.

Key words: Trypanosoma cruzi - Didelphis marsupialis - Rattus rattus - genital transmission - histotropism cyclophosphamide

Flagellates, bacteria, and viruses have been found in menstrual blood, semen, and vaginal fluid, and also adhering to spermatozoa (Smith \& Dobson 1992, Profet 1993, Silverman et al. 1994). Blood flagellates of the genera Leishmania and Trypanosoma have been observed in urine, macrophages of genital mucosa, semen, and the mucous exudate of the penis (Symmers 1960, Hoare 1972, Uche \& Jones 1992, Mebrahtu et al. 1993). Bloodstream forms of $T$. cruzi have been observed mixed with sperm (Vianna 1911, Lamano Carvalho et al. 1991), in urine (Zeledón 1974), and in almost all urogenital organs of experimental animals (Herrera \& Urdaneta-Morales 1992, Lenzi et al. 1996). Thus, to investigate the possibility of transmission through the mucosa of the genitalia, we instilled contaminated blood into the vagina and

This study was funded by the Consejo de Desarrollo Científico y Humanístico de la Universidad Central de Venezuela, grant no. 033137-0298.

${ }^{+}$Corresponding author. Fax: +58-212-7535897

E-mail: surdanet@strix.ciens.ucv.ve

Received 5 July 2000

Accepted 22 March 2001 penis of mice, and also injected it into the male scrotum.

\section{MATERIALS AND METHODS}

Three strains of $T$. cruzi were employed: $\mathrm{CO} 22$, isolated from a naturally infected rat, Rattus rattus (Herrera \& Urdaneta-Morales 1997); CO57 from a naturally infected opossum, Didelphis marsupialis and human EP (Torrealba 1970). The first two strains were from animals captured in urban areas of Caracas, Venezuela. The experimental animals were heterozygous NMRI mice.

In the first experiment, six females, neither pregnant nor virgin, $30 \mathrm{~g}$, were instilled intravaginally with $10^{3}$ trypomastigotes using $5 \mu 1$ micropipettes (Sigma Chem Co USA) with blood obtained by cardiopuncture from mice with $2 \times 10^{5}$ trypomastigotes $/ \mathrm{ml}$ blood of strain $\mathrm{CO} 22$. The six females were divided into two groups: a group of four females with one healthy male, and a group of two females that were not allowed to copulate during the experiment. For these females, $1 \mathrm{~h}$ after instillation, the vagina was washed with $5 \mu$ sterile saline, which was examined fresh at 400X; additional washings were examined at 8 and $24 \mathrm{~h}$.

Of four males, two were instilled with the same dose through the external meatus of the urethra with 
the prepuce retracted; the males were allowed to copulate with two healthy females the same day of the instillation and then during the experiment. The other two males were injected into one side of the scrotum with $0.05 \mathrm{ml}$ of the infective blood, using a 26 gauge needle.

All animals were anaesthetised before infection by intramuscular injection of $0.02 \mathrm{ml}$ ketaset (Ketamine HC1 100 mg/ml, Fort Dodge Labs, USA).

Further experiments were made varying inocula and weight of animals. Blood inocula of $2 \times 10^{4}$ trypomastigotes were instilled into two groups of three females of 20 and $30 \mathrm{~g}$; of $6 \times 10^{4}$ into six females of $30 \mathrm{~g}$; and $1.2 \times 10^{5}$ into six females and six males of $20 \mathrm{~g}$ that were not allowed to copulate.

To study the effect of impaired immune response, those animals instilled with the $6 \times 10^{4}$ blood trypomastigote inoculum were immunosuppressed 30 days later by ip injection of $10 \mathrm{mg} / \mathrm{kg}$ cyclophosphamide (Endoxan-Asta, Asta-Werke, AG, Germany), according to Calabrese et al. (1996), three times a week until death. For controls, two groups of two females were instilled by eye and by mouth with $6 \times 10^{4}$ blood trypomastigotes and immunosuppressed as above.

Examinations of fresh tail blood at $400 \mathrm{X}$ were made on the inoculated animals three times a week; flagellates were counted by the method of Brener (1962). When examinations were negative, blood taken in a heparinized microhematocrit pipette (Camargo \& Takeda 1979) was centrifuged at $8,000 \mathrm{x} \mathrm{g}$ for $30 \mathrm{~min}$ and parasites searched for in the buffy coat. Three weeks post-inoculation, the animals were xenodiagnosed with 12 III and IVthstage laboratory-bred nymphs of Rhodnius prolixus; these were examined three weeks later (Perlowagora \& Moreira 1994).

The experiments with strain $\mathrm{CO} 22$ were repeated with strains CO57 and EP on mice $30 \mathrm{~g}$, using $10^{4}$ blood trypomastigotes per mouse. For each of these strains six females were instilled intravaginally, three males into the penis, and three males injected into the scrotum. Four female controls were instilled orally and into the eyes. Male mice were allowed to copulate with healthy females the same day of the instillation and then throughout the experiment. Mortality was recorded daily.

Animals showing the highest parasitemias, based on growth curves, induced by genital infections were sacrificed by cervical dislocation, and samples of heart, skeletal muscle, skin, sternum, lung, liver, spleen, colon, duodenum, pancreas, brain, lymph nodes, testis, epididymis, vas deferens, seminal vesicle, ovary, urinary bladder and kidney were taken for preparing $5 \mu \mathrm{m}$ sections to be stained with hematoxylin-eosin. Presence of parasites in the sections was determined by two independent observers. The parasites were photographed with a Nikon Microflex HPX-35 camera on Ilford Pan-F film.

\section{RESULTS}

Intravaginal instillation produced systemic infections with strain $\mathrm{CO} 22$, with inocula of 2 and $6 \times 10^{4}$ and $1.2 \times 10^{5}$ blood trypomastigotes. The respective highest parasitemias in the infected animals, based on growth curves, averaged: $2 \times 10^{4}$ trypomastigotes $/ \mathrm{ml}$ in direct examination of $20 \mathrm{~g}$ mice; $6 \times 10^{3} / \mathrm{ml}$ by centrifuged buffy coat in $30 \mathrm{~g}$ mice, and $6 \times 10^{4}$ trypomastigotes $/ \mathrm{ml}$ in direct examination of $20 \mathrm{~g}$ mice. Cyclophosphamide immunosuppression of vaginally infected females with the $6 \times 10^{4}$ blood trypomastigote inoculum, did not increase significantly the parasitemia ( $\mathrm{F} \mathrm{ra}-$ tio $=203388, p$-value of the F-test $\geq 0.05$ ); the maximum was $1.3 \times 10^{4}$ trypomastigotes $/ \mathrm{ml}$. The control mice infected by mouth and by eye had low parasitemias $\left(6 \times 10^{3}\right.$ flagellates $\left./ \mathrm{ml}\right)$; cyclophosphamide treatment did not increase the parasitemias more than to $2 \times 10^{4}$ and $8 \times 10^{4}$ flagellates $/ \mathrm{ml}$ in ocular and oral infections, respectively $(\mathrm{F}$ ratio $=1.32551$ for oral route; $\mathrm{F}$ ratio $=$ 3.09009 for ocular route; $p$-value of the F-test $\geq$ 0.05 for twice routes).

The instilled animals allowed to copulate did not infect their healthy partners. Trypomastigotes were not observed in vaginal washings of isolated female mice.

Instillation into the penis was successful with the inoculum of $1.2 \times 10^{5}$ blood trypomastigotes with strain $\mathrm{CO} 22$; the infection was detected by xenodiagnosis. Relaxation of the sphincters was observed. Those mice instilled in the vagina and penis that were negative by centrifuged blood were also all negative by xenodiagnosis.

All mice inoculated into the scrotum were infected with all three strains. The average maximum parasitemias were of $4.5 \times 10^{4}, 4 \times 10^{5}$, and $3.5 \times$ $10^{6}$ flagellates $/ \mathrm{ml}$, for strains $\mathrm{CO} 22$, CO57, and EP, respectively. Scrotal infections induced relaxation of sphincters, paralysis of hind legs, and necrosis of the scrotum.

Histological sections of mice intravaginally instilled with strain $\mathrm{CO} 22\left(1.2 \times 10^{5}\right.$ trypomastigotes $/ \mathrm{ml}$ ) showed invasion of heart, skeletal muscle, skin (dermis connective tissue and sebaceous gland), duodenum (lamina propria and muscular layer), pancreas (acini), perichondrium, marrow, and connective tissue of the sternum, ovary (stroma) and adjacent fatty tissue.

Intrascrotal inoculation with strain $\mathrm{CO} 57$ produced invasion of heart, skeletal muscle, pancreas, testis (tunica albuginea) and vas deferens (smooth 
muscle). Strain EP also invaded the liver (very large pseudocysts), spleen, lung (alveolar wall), urinary bladder (mucosa close to the lumen and smooth muscle), kidney, testis (tunica albuginea and in- terstitial connective tissue), epididymis (ductus epithelium and connective tissue and adjacent adipose tissue), seminal vesicle (muscular layer), skin, sternum and lymph nodes (Figure).

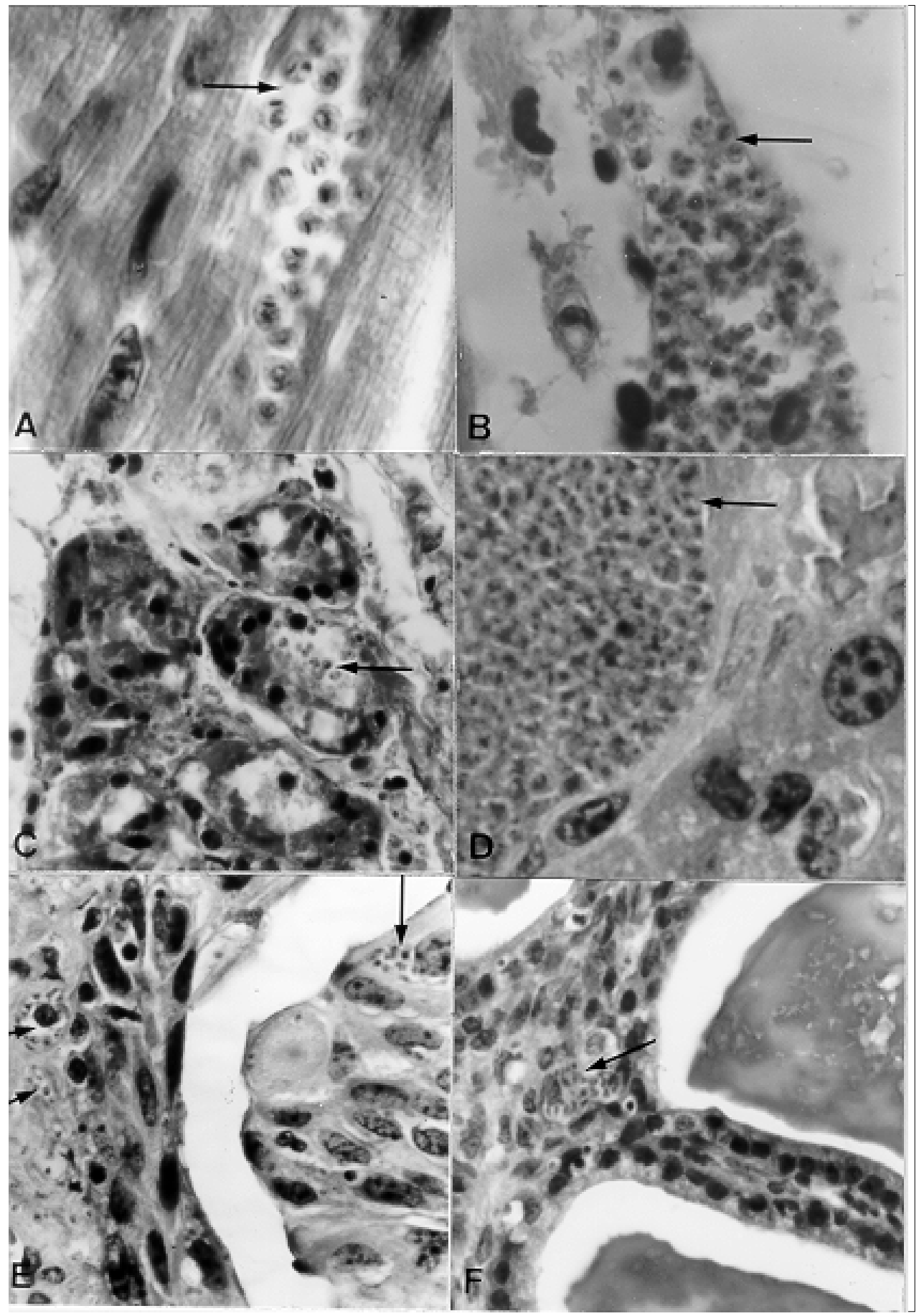

Histological sections from albino mice intravaginally instilled with strain $\mathrm{CO} 22$ of Trypanosoma cruzi from Rattus rattus, and scrotally inoculated with strain EP from human, showing nests (arrows) with amastigotes in A: cardiac tissue; B: skeletal muscle; C: pancreas (acinus); D: liver; E: urinary bladder (epithelium, very close to the lumen, and lamina propria); F: seminal vesicle (mucosa close to the lumen). A-C: strain CO22; D-F: strain EP. A, B, D: 1400X; C, E, F: 950X Hematoxilyn-Eosin) 


\section{DISCUSSION}

The usual vectorial transmission by $T$. cruzi arises when fecal metacyclics of the infected triatomine make contact with mucous membrane or injured skin of the mammalian host (Dias 1979). Congenital transmission and infection from maternal milk with blood trypomastigotes (Chimelli \& Scaravilli 1997) are also implicated in infection, bypassing the vector.

The urogenital organs are regularly parasitized in experimental infections (Bice \& Zeledón 1970, Herrera \& Urdaneta-Morales 1992, Tavares et al. 1994, Lenzi et al. 1996, Scorza et al. 1996). Blood trypomastigotes have been isolated from the urine of opossums and mice (references in Zeledón 1974). Lenzi et al. (1996) reported that T. cruzi can mix with spermatozoa through the seminiferous tubules and the epididymus; Lamano et al. (1991) also found parasites in or near these organs of experimental animals and Alencar et al. (1987) observed parasite nests in the muscle cells of the seminal ducts. T. cruzi has been found in the skin around and in all organs involved in coitus, including the prepuce (references in Herrera \& UrdanetaMorales 1992, Tavares et al. 1994, Lenzi et al. 1996). Dias (1979) mentioned that the presence of $T$. cruzi in the chagasic females' menstrual blood could suggest the possibility of transmission through coitus.

Chimelli and Scaravilli (1997) have suggested transmission through mucosa by maternal blood. In our study, 6 out of 36 females instilled into the vagina became infected, as did 2 out of 14 males instilled into the penis, showing that the mucosa of these organs can be penetrated by the blood form of the parasite, although some workers have found that blood trypomastigotes were less capable of infecting tissues (references in Zeledón et al. 1977). Our study appears to show that genital instillation and scrotal inoculation are no less effective than the ip injection employed for isolation of the strains used (Torrealba 1970, Herrera \& Urdaneta-Morales 1997).

All infected mice died, although those inoculated with strain $\mathrm{CO} 22$ had low parasitemias and a limited range of tissue tropism. This appears to show that virulence, tropism, and pathogenicity of this strain are unrelated, as has been reported for other strains and clones (Lauria-Pires \& Teixeira 1996). The results also reveal intraspecific differences in isolates of $T$. cruzi from different reservoirs and vectors (references in Scorza et al. 1996, Lauria-Pires \& Teixeira 1996, Briones et al. 1999).

The parasite has been found in the genitalia of immunocompromised mice (Calabrese et al. 1994) and in human HIV patients (Rocha et al. 1994). It would be logical to search for T. cruzi in menstrual blood and in the sexual secretions.

The reduced virulence seen with instillation into the penis suggests that highly vascularized organs may resist penetration of $T$. cruzi (Lenzi et al. 1996).

According to Profet (1993), in mammals the spermatozoa themselves are the vectors for pathogens, rather than the seminal fluid; in women, estrus is the period during which defense against pathogens is highest, thus inhibiting coital transmission. Mucosal immunity as a surface protection system (Brandtzaeg et al. 1999) against genital tract parasitic flagellates deserves further investigation.

\section{ACKNOWLEDGMENTS.}

To Julio Zambrano for technical assistance and Estefanía Flores for the histological preparations. To Dr Marian Ulrich for many helpful comments on the English version of the manuscript and aid in preparation and to an anonymous referee who improved the manuscript.

\section{REFERENCES}

Alencar A, Brito C, Azevedo B 1987. Involvement of the male genital apparatus in Chagas' disease. Experimental study with albino mice (possibility of transmission of the disease through the semen). Mem Inst Oswaldo Cruz (Suppl.) 82: 59.

Bice D, Zeledón R 1970. Comparison of infectivity of strains of Trypanosoma cruzi (Chagas, 1909). J Parasitol 56: 663-670.

Brandtzaeg P, Baekkevold E, Farstad I 1999. Regional specialization in the mucosal immune system: what happens in the microcompartments? Immunol Today 20: 141-151.

Brener Z 1962. Therapeutic activity and criterion of cure of mice experimentally infected with Trypanosoma cruzi. Rev Inst Med Trop São Paulo 4: 389-396.

Briones M, Souto R, Stolf B, Zingales B 1999. The evolution of two Trypanosoma cruzi subgroups inferred from rRNA genes can be correlated with the interchange of American mammalian faunas in the Cenozoic and has implications to pathogenicity and host specificity. Mol Bioch Parasitol 104: 219-232.

Calabrese K, Lagrange P, Gonçalves da Costa S 1994. Trypanosoma cruzi: histopathology of endocrine system in immunocompromised mice. Int J Exp Pathol 75: 453-462.

Calabrese K, Lagrange P, Gonçalves da Costa S 1996. Chagas' disease: enhancement of systemic inflammatory reaction in cyclophosphamide treated mice. Int J Immunopharm 18: 505-514.

Camargo M, Takeda G 1979. Diagnóstico de laboratório. In Z Brener, Z Andrade (eds), Trypanosoma cruzi e Doença de Chagas, Guanabara Koogan, Rio de Janeiro, p. 175-198.

Chimelli L, Scaravilli F 1997. Trypanosomiasis. Brain Pathol 7: 599-611.

Dias JCP 1979. Mecanismos de transmissão. In Z Brener, 
Z Andrade (eds), Trypanosoma cruzi e Doença de Chagas, Guanabara Koogan, Rio de Janeiro, p. 152174.

Herrera L, Urdaneta-Morales S 1992. Didelphis marsupialis: a reservoir of Trypanosoma cruzi in urban areas of Caracas, Venezuela. Ann Trop Med Parasitol 86: 607-612.

Herrera L, Urdaneta-Morales S 1997. Synanthropic rodent reservoirs of Trypanosoma cruzi in the valley of Caracas, Venezuela. Rev Inst Med Trop São Paulo 39: 279-282.

Hoare C 1972. The Trypanosomes of Mammals, Blackwell, Oxford, 749 pp.

Lamano Carvalho T, Ribeiro R, Lopez R 1991. The male reproductive organs in experimental Chagas' disease. I. Morphometric study of the vas deferens in the acute phase of the disease. Exp Pathol 41: 203-214.

Lauria-Pires L, Teixeira A 1996. Virulence and pathogenicity associated with diversity of Trypanosoma cruzi stocks and clones derived from Chagas' disease patients. Am J Trop Med Hyg 55: 304-310.

Lenzi H, Oliveira D, Lima M, Gattas C 1996. Trypanosoma cruzi: paninfectivity of CL strain during murine acute infection. Exp Parasitol 84: 16-27.

Mebrahtu Y, Hendricks L, Oster C, Lawyer P, Perkins P, Roberts C 1993. Leishmania donovani parasites in the nasal secretions, tonsillopharyngeal mucosa, and urine centrifugates of visceral leishmaniasis patients in Kenya. Am J Trop Med Hyg 48: 530-535.

Perlowagora A, Moreira C 1994. In vivo differentiation of Trypanosoma cruzi. 1. Experimental evidence of the influence of vector species on metacyclogenesis. Mem Inst Oswaldo Cruz 89: 603-618.

Profet M 1993. Menstruation as a defense against pathogens transported by sperm. Quart Rev Biol 68: 335386.

Rocha A, Meneses A, Silva A, Ferreira M, Nishioka M, Lopes E 1994. Pathology of patients with Chagas' disease and adquired immunodeficiency syndrome. Am J Trop Med Hyg 50: 261-268.

Scorza C de, Herrera L, Urdaneta-Morales S 1996. Trypanosoma cruzi: histopathology in mice infected with strains isolated from Didelphis marsupialis from the valley of Caracas (Venezuela). Acta Cient Venez 47: 244-247.

Silverman A, Puccio J, Kulesza G, McCray D, Gordon S 1994. HCV RNA is present in the menstrual blood of women with chronic hepatitis C infection. Am J Gastroenterol 89: 1201-1202.

Smith G, Dobson A 1992. Sexually transmitted diseases in animals. Parasitol Today 8: 159-166.

Symmers W 1960. Leishmaniasis acquired by contagion. Lancet Jan.: 127-132.

Tavares M, Carraro A, Favaretto A, Petenusci S, Lamano Carvalho T 1994. The male reproductive organs in experimental Chagas' disease. Exp Toxic Pathol 46: 243-246.

Torrealba AB 1970. Observaciones sobre el Comportamiento en Ratón Blanco de una Cepa Humana de Trypanosoma cruzi, Thesis, Universidad Central de Venezuela, Caracas, 56 pp.

Uche U, Jones T 1992. Pathology of experimental Trypanosoma evansi infection in rabbits. J Comp Pathol 106: 299-309.

Vianna G 1911. Contribuição para o estudo da anatomia patológica da "Molestia de Chagas". Mem Inst Oswaldo Cruz 3: 276-294.

Zeledón R 1974. Epidemiology, modes of transmission and reservoir hosts of Chagas' disease. In Trypanosomiasis and Leishmaniasis with Special Reference to Chagas'Disease, Ciba Found Symp 20, Elsevier, New York, p. 51-85.

Zeledón R, Trejos M de, Chinchilla M 1977. Experimental infection of mice with blood, culture and insect forms of Trypanosoma cruzi by different routes. Protozoology 3: 95-101. 